\title{
Bibliometric Investigation of Registered Master's and Doctoral Thesis Prepared Under the Title of Environmental Problems in Turkey
}

\author{
Bülent ESKİN ${ }^{*}$ \\ Ahmet KURT ${ }^{2}$ \\ ${ }^{1}$ Aksaray University, Faculty of Economics and Administrative Sciences, Department of Urbanization and Environmental Problems, Aksaray, Turkey. \\ ${ }^{2}$ Aksaray University, Social Sciences Institute, Department of Public Administration, Aksaray, Turkey.
}

How to cite: Eskin, B. \& Kurt, A. (2020). Bibliometric Investigation of Registered Master's and Doctoral Thesis Prepared Under the title of Environmental Problems in Turkey. J. Anatolian Env. and Anim. Sciences, 5(4), 676-684. Atıf yapmak için: Eskin, B. \& Kurt, A. (2020). Türkiye'de Çevre Sorunları Başlığı Altında Hazırlanmış Kayıtlı Yüksek Lisanas ve Doktora Tezlerinin Bibliyometrik İncelenmesi. Anadolu Çev. ve Hay. Dergisi, 5(4), 676-684.

: https://orcid.org/0000-0002-7990-4138 iD : httns://orcid.org/0000-0001-8595-867X
*Corresponding author's: Bülent ESKIN

Aksaray University, Faculty of Economics and Administrative Sciences, Department of Urbanization and Environmental Problems, Aksaray, Turkey.

\: b eskin@hotmail.com

Mobile telephone: +90 (505) 8520451

Telephone : $+90(382) 2882470$

Fax : $\quad+90(382) 2882549$
Abstract: Countries in the world have begun to pay more attention to environmental problems in recent years. Because these problems have threatened human life in every aspect and without limit. Climate changes, rising temperatures, melting of glaciers, and the change of natural vegetation are among the threatening environmental issues and many countries act together in the international area on these issues. Protection of ecological balance and natural life, use of renewable energy sources, recycling of wastes, environmentally friendly production methods are strong solutions to be brought to environmental problems. In addition, original academic studies should be conducted to bring solution to the these issues. In this context, bibliometric studies, which is one of the most important reference sources of science policies, come to the fore. In these studies, publications produced by individuals or institutions are analyzed after determining their subject, period and region. In this context, the main purpose of this study is to investigate the master and doctorate theses registered under the title of environment problems in the Thesis Center of the Council of Higher Education between 1978-2018 in line with various parameters by using bibliometric analysis technique. In accordance with this purpose, environmental problems were written in the search section of the web page of the Thesis Center of the Higher Education Council and the master's and doctorate theses were analyzed in detail. 214 master's and doctoral theses have written under the title of urbanization in Turkey by the end of 2018. 36 of these theses are doctoral theses and 178 of them are master's theses. In the scope of the subject, bibliometric studies can be performed on topics such as environment, environmental policy and environmental law in the following years except for the title of environmental problems. In addition, in these subjects comparisons between countries, branches of science and public and private sectors producing publications will be useful for contributing to the literature.

Keywords: Bibliometric study, doctoral thesis, environmental problems, master thesis.

\section{Türkiye'de Çevre Sorunları Başlığı Altında Hazırlanmış Kayıtlı Yüksek Lisans ve Doktora Tezlerinin Bibliyometrik İncelenmesi}

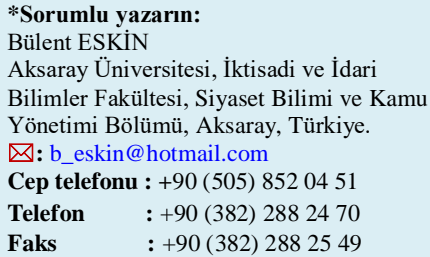

Öz: Dünyadaki ülkeler son yıllarda çevre sorunlarına daha fazla önem vermeye başlamıştır. Çünkü bu sorunlar insan hayatını her yönüyle ve sınır tanımaksızın tehdit etmektedir. İklim değişiklikleri, sıcaklıkların artması, buzulların erimesi ve doğal bitki örtüsünün değişim göstermesi tehdit unsuru içeren çevre sorunları arasındadır ve uluslararası alanda birçok ülke bu konularda beraber hareket etmektedir. Ekolojik dengenin ve doğal hayatın korunması, yenilenebilir enerji kaynaklarının kullanılması, atıkların geri dönüşümü ve doğa dostu üretim biçimleri çevre sorunlarına getirilecek güçlü çözümlerdir. Ayrıca, bu konulara çözüm getirmek için özgün akademik çalışmalar yapılmalıdır. Bu bağlamda, bilim politikalarının en önemli referans kaynaklarından biri olan bibliyometrik çalışmalar ön plana çıkmaktadır. Bu çalışmalarda, bireyler veya kurumlar tarafından üretilen yayınlar, konusu, dönemi ve bölgesi belirlendikten sonra analiz edilmektedir. Bu kapsamda, bu çalışmanın amacı, 1978-2018 yılları arasında Yükseköğretim Kurulu Tez Merkezinde çevre sorunları başlığı altında kaydedilen yüksek lisans ve doktora tezlerini, bibliyometrik analiz tekniğini kullanarak çeşitli parametreler doğrultusunda incelemektir. Bu amaç doğrultusunda, Yükseköğretim Kurulu Tez Merkezinin web sayfasının arama bölümüne çevre sorunları yazılmış ve yüksek lisans ve doktora tezleri ayrıntılı olarak incelenmiștir. 2018 yılı sonuna gelindiğinde Türkiye'de çevre sorunları başlığı altında 214 lisansüstü tez yazılmıştır. Bu tezlerin 36 tanesi doktora tezi, 178 tanesi ise yüksek lisans tezidir. Konu kapsamında çevre sorunları başlığı dışında çevre, çevre politikası ve çevre hukuku gibi konularda da önümüzdeki yıllarda bibliyometrik çalışmalar yapılabilir. Ayrıca, bu konularda ülkeler, bilim dalları ve yayın üreten kamu ve özel sektör arasındaki karşılaştırmalar literatüre katkıda bulunmak adına yararlı olacaktır.

Anahtar kelimeler: Bibliyometrik calıșma, doktora tezi, cevre sorunları, yüksek lisans. 


\section{INTRODUCTION}

In recent years, states have started to attach more and more importance to this issue since environmental problems threaten human life in every aspect and without any boundaries. Climate changes, rising temperatures, melting glaciers, storms and changing natural vegetation have enabled many countries to act together internationally. Additionally, these threats to the environment are recognized as global problems rather than national problems (Baykal \& Baykal, 2008).

Considering that the quality of the environment is affected by the global structure even within the borders of a country, implementing the rules to be determined by the global environmental authority as a country will be a strong solution to protect living spaces worldwide (Kaypak, 2013). In this context, protecting ecological balance and natural life, using renewable energy sources such as wind, sun, recycling urban and industrial wastes, using naturefriendly production forms and products and increasing the quality and quantity of green environment in urban areas are strong solutions to be brought to the environmental problems of a global nature by countries. There are also a need for original academic studies that will bring solutions with analytical approach to these issues in Turkey. In this context, bibliometric studies, one of the most important reference sources of science policies, come to the fore.

In bibliometric studies, publications specific to a field of science produced by individuals or institutions in a certain period and in a certain region and the relationships between these publications are analysed numerically (Tubitak Ulakbim Cahit Arf Information Center, 2020). In such researches that researchers apply for different reasons, researches in a certain area and researchers are identified. In addition, there are the opportunities to make comparisons between countries, schools and institutions on different topics with bibliometric studies (Koehler, 2001). For this purpose, scientists increase the level of relationship between their studies by conducting factor analysis as well as statistical techniques such as regression and correlation in their academic study (Subramanyam, 1982).

It is noteworthy that in today's world there are new developments in science and a rapid increase in knowledge. In addition, previous scientific studies make a great contribution to the branches of science. At this point, the institutions that enable the sharing of scientific information with the application area, help to convey the information produced in a way that contributes to the relevant field. Institutions provide this information sharing through their publications and digital environment (Taşkın \& Çakmak, 2010).
Countries should put their science and technology policies on a healthy basis. In this context, quantitative and qualitative characteristics of the publications produced by the scientific community in Turkey should be questioned and policies should be constituted to improve these qualifications (Al, 2008). For this purpose, the National Council of Higher Education Thesis Center in Turkey has made its data accessible electronically to contribute to science, to support scientific research and activities.

Within the scope of this study, in which bibliometric analysis technique is used, between 19782018 under the title of environmental problems it is aimed to determine the master's and doctoral theses registered at the Higher Education Council's Thesis Center in line with various parameters. In addition, another aim of this study is to gather the findings under a single study framework and to reach a large number of study data from a single source.

\section{MATERIAL AND METHODS}

The main material of this study consists of domestic and foreign primary and secondary sources obtained as a result of the literature review, and master's and doctoral theses registered in the National Thesis Center of the Higher Education Council. During the preparation of the study, university and municipal libraries, various electronic libraries, internet search engines, Higher Education Council thesis scanning page and scientific articles published on this subject were used.

In this study, between the years 1978-2018, master's and doctoral theses are made under the heading of environmental problems in Turkey were investigated using bibliometric analysis technique in accordance with various parameters. Accordingly, a detailed analysis of master's and doctoral theses was made by writing the keyword "environmental issues" in the screening section of the Higher Education Council's Thesis Center website. The type, method, language of the thesis, number of pages, accessibility status, year of writing, university where it was published, institute where it was published, department of publication, consultant title and province where it was made are among the bibliometric parameters used in the study.

\section{RESULTS}

Bibliometric studies are very popular today and many issues have been identified with bibliometric analysis in Turkey. It is easy to follow the development process of a science field thanks to the studies prepared by using bibliometry.

When literature has been investigated, it is possible to reach many studies about master's and doctorate 
thesis prepared in Turkey. Satır's (1998) thesis titled as "Bibliometric analyses" is one of the first works prepared on this subject.

In Turkey 25 master's and doctoral thesis on bibliometrics total under the title is written until today. 11 of these theses (Table 1) were written in 2019 and 2020 (Council of Higher Education Thesis Center, 2019).

\section{Bibliometric Investigation: The} https://tez.yok.gov.tr/UlusalTezMerkezi/tezSorguSonucY eni.jsp web address of the Council of Higher Education Thesis Center was used in all investigations made under this title.

There are 214 doctorate and master's thesis written (Table 2) under the heading of environmental problems in Turkey by the end of 2018. 36 of these theses are doctoral theses and 178 of them are master's theses. Doctorate theses constitute $16.82 \%$ of the total theses. On the other hand master's theses constitute $83.18 \%$ of the total thesis.

Table 1. Bibliometric theses written at the master's and doctorate in recent years (Council of Higher Education Thesis Center, 2019).

\begin{tabular}{|c|c|c|}
\hline Title of Thesis & Thesis Type & Subject \\
\hline $\begin{array}{l}\text { A comprehensive bibliometric analysis of documents of } \\
\text { organization theories on social entrepreneurship } \\
\text { (Akkocaoglu, 2019) }\end{array}$ & Master's & $\begin{array}{c}\text { Business } \\
\text { Administration }\end{array}$ \\
\hline $\begin{array}{l}\text { Ethics in STS: A bibliometric exploratory study (Oguz, } \\
2019)\end{array}$ & Master's & $\begin{array}{l}\text { Science and } \\
\text { Technology }\end{array}$ \\
\hline $\begin{array}{l}\text { A bibliometric analysis of critical construction } \\
\text { management studies (Deniz, 2019) }\end{array}$ & Master's & Architecture \\
\hline $\begin{array}{l}\text { Tourism and Islamophobia in the field of Bibliometric } \\
\text { Analysis (Coskun, 2020) }\end{array}$ & Master's & $\begin{array}{l}\text { Religion, } \\
\text { Tourism }\end{array}$ \\
\hline $\begin{array}{l}\text { Bibliometric analysis of cultural tourism studies } \\
\text { (Altuntop, 2019) }\end{array}$ & Master's & Tourism \\
\hline $\begin{array}{l}\text { Evaluation of scientific publications in international } \\
\text { trade with social network analysis: A bibliometric study } \\
\text { (Cinar 2019) }\end{array}$ & Master's & $\begin{array}{l}\text { Economics, } \\
\text { Business } \\
\text { Administration }\end{array}$ \\
\hline $\begin{array}{l}\text { Examination of concept of open innovation in the } \\
\text { World and Turkey with bibliometric, content and } \\
\text { document analysis (Percin, 2019) }\end{array}$ & Master's & $\begin{array}{c}\text { Business } \\
\text { Administration }\end{array}$ \\
\hline $\begin{array}{l}\text { Bibliometric analysis of management information } \\
\text { systems discipline (Kefkir, 2019) }\end{array}$ & Master's & $\begin{array}{c}\text { Business } \\
\text { Administration }\end{array}$ \\
\hline $\begin{array}{l}\text { The early stages of organization and management } \\
\text { studies in North America and Europe: A bibliometric } \\
\text { analysis (Emre, 2019) }\end{array}$ & Master's & $\begin{array}{c}\text { Business } \\
\text { Administration }\end{array}$ \\
\hline $\begin{array}{l}\text { Bibliometric analysis of organizational behaviour } \\
\text { research (Karaboga, 2019) }\end{array}$ & Master's & $\begin{array}{l}\text { Bibliography, } \\
\text { Business } \\
\text { Administration }\end{array}$ \\
\hline $\begin{array}{l}\text { Bibliometric analysis of theses in music abstract } \\
\text { (Aksaray, 2019) }\end{array}$ & Master's & Music \\
\hline
\end{tabular}

Table 2. Distribution of master's and doctorate theses under title of environmental problems.

\begin{tabular}{lcc}
\hline Type & Frequency & \% \\
\hline Doctorate Theses & 36 & 16.82 \\
Master's Theses & 178 & 83.18 \\
Total & $\mathbf{2 1 4}$ & $\mathbf{1 0 0}$ \\
\hline
\end{tabular}

96 out of 214 master and doctorate theses which are registered in the National Thesis Center of Higher Education Council, were written using qualitative research methods and 73 of them were written using quantitative research methods. 13 thesis were written (Table 3 ) by using mixed research methods. The research method of 32 theses could not be determined.

Table 3. Distribution of master and doctorate theses under the title of environmental problems according to research method.

\begin{tabular}{lcccc}
$\begin{array}{l}\text { Research } \\
\text { Methods }\end{array}$ & Doctorate & Master's & $\begin{array}{c}\text { Total } \\
\text { Frequency }\end{array}$ & \% \\
\hline Qualitative & 16 & 80 & 96 & 44.86 \\
Quantitative & 15 & 58 & 73 & 34.11 \\
Mixed & 1 & 12 & 13 & 6.07 \\
Undetectable & 4 & 28 & 32 & 14.95 \\
Total & $\mathbf{3 6}$ & $\mathbf{1 7 8}$ & $\mathbf{2 1 4}$ & $\mathbf{1 0 0}$ \\
\hline
\end{tabular}

According to the information obtained from the National Thesis Center of the Council of Higher Education, all 36 doctoral theses in the field of environmental problems were written in Turkish. 174 of the 178 master's theses were written (Table 4) in Turkish On the other hand 4 theses were written in English. In grand total, 98.13\% of the doctoral and master's theses were written in Turkish and $1.87 \%$ in English.

Under the heading of environmental problems in Turkey, the ratio of master's and doctoral theses written between 101 and 200 pages, is $56.07 \%$. The rate of thesis written under 100 pages is $25.23 \%$. Also $15.42 \%$ of the written theses in Turkey are between 201 and 300 pages. And there are $3.27 \%$ theses between 301 and 400 pages. There is no thesis written over 400 pages (Table 5).

Table 4. Distribution of master's and doctoral theses under title of environmental problems according to their language.

\begin{tabular}{|c|c|c|c|c|c|c|}
\hline \multirow[t]{2}{*}{ Language of Thesis } & \multicolumn{2}{|c|}{ Doctorate } & \multicolumn{2}{|c|}{ Master's } & \multicolumn{2}{|c|}{ Total } \\
\hline & Frequency & $\%$ & Frequency & $\%$ & Frequency & $\%$ \\
\hline Turkish & 36 & 100 & 174 & 97.75 & 210 & 98.13 \\
\hline English & - & - & 4 & 2.25 & 4 & 1.87 \\
\hline Total & 36 & 100 & 178 & 100 & 214 & 100 \\
\hline
\end{tabular}

Table 5. Distribution of master's and doctoral theses under title of environmental problems according to number of pages

\begin{tabular}{|c|c|c|c|c|}
\hline Number of pages & Doctorate & Master's & Total Frequency & $\%$ \\
\hline $0-100$ & 2 & 52 & 54 & 25.23 \\
\hline $101-200$ & 10 & 110 & 120 & 56.07 \\
\hline $201-300$ & 18 & 15 & 33 & 15.42 \\
\hline $301-400$ & 6 & 1 & 7 & 3.27 \\
\hline Total & 36 & 178 & 214 & 100 \\
\hline
\end{tabular}

23 from a total of 36 doctoral theses written under the title of environmental problems in Turkey is accessible thesis. 13 of them are inaccessible theses. In addition, 91 of the 178 master's theses written are accessible. In addition 87 master theses are inaccessible (Table 6). In overall total,
114 of the doctoral and master's theses written are accessible, while 100 are not. The total accessibility rate of the theses is $53.27 \%$. The inaccessible thesis rate is $46.73 \%$. 
Table 6. Accessibility status of master's and doctorate theses titled environmental problems.

\begin{tabular}{|c|c|c|c|c|c|c|}
\hline \multirow[b]{2}{*}{ Accessibility } & \multicolumn{2}{|c|}{ Doctorate } & \multicolumn{2}{|c|}{ Master's } & \multicolumn{2}{|c|}{ Total } \\
\hline & Frequency & $\%$ & Frequency & $\%$ & Frequency & $\%$ \\
\hline Accessible Thesis & 23 & 63.89 & 91 & 51.12 & 114 & 53.27 \\
\hline Inaccessible Thesis & 13 & 36.11 & 87 & 48.88 & 100 & 46.73 \\
\hline Total & 36 & 100 & 178 & 100 & 214 & 100 \\
\hline
\end{tabular}

1994, 1997, 2010 are the years when the doctoral theses written in the field of environmental problems are the highest with $8.3 \%$ (Table 7). Doctoral theses were not written in 1988, 1989, 1991, 1998, 1999, 2001, 2002, 2003, 2007 and 2017 in this topic.

1996 is the year when the master's theses written in the field of environmental problems are the highest with $6.74 \%$. In 1978 and 1987, no master thesis on environmental problems have written in Turkey.

1996 and 2010 are the years when the highest master's and doctoral thesis have been written with $6.74 \%$ under the title of environmental problems. In addition, there have no master's and doctoral thesis on environmental problems in 1988 and between 1978 and 1987.

Under the heading of environmental problems in Turkey 214 theses were written. 132 of these theses were prepared within the institutes of social sciences. 44 of them (Table 8) were prepared at the Graduate School of Natural and Applied Sciences. Institute of Marine Sciences and Management, The Graduate School of Engineering \& Sciences, Middle East Technical University- Northern Cyprus Campus- Graduate School of Natural and Applied Sciences, Institute of Middle East Studies are institutes which have been written only one thesis.

Table 7. Distribution of master's and doctoral theses titled environmental problems by years.

\begin{tabular}{|c|c|c|c|c|c|c|}
\hline \multirow{2}{*}{ Years } & \multicolumn{2}{|c|}{ Doctorate } & \multicolumn{2}{|c|}{ Master's } & \multicolumn{2}{|c|}{ Total } \\
\hline & Frequency & Percentage (\%) & Frequency & Percentage (\%) & Frequency & Percentage (\%) \\
\hline 1978 & 2 & 5.56 & - & - & 2 & 0.93 \\
\hline 1987 & 1 & 2.78 & - & - & 1 & 0.47 \\
\hline 1989 & - & - & 1 & 0.56 & 1 & 0.47 \\
\hline 1990 & 1 & 2.78 & 3 & 1.69 & 4 & 1.87 \\
\hline 1991 & - & - & 7 & 3.93 & 7 & 3.27 \\
\hline 1992 & 1 & 2.78 & 5 & 2.81 & 6 & 2.80 \\
\hline 1993 & 1 & 2.78 & 8 & 4.49 & 9 & 4.21 \\
\hline 1994 & 3 & 8.33 & 1 & 0.56 & 4 & 1.87 \\
\hline 1996 & 2 & 5.56 & 12 & 6.74 & 14 & 6.54 \\
\hline 1997 & 3 & 8.33 & 5 & 2.81 & 8 & 3.74 \\
\hline 1998 & - & - & 6 & 3.37 & 6 & 2.80 \\
\hline 1999 & - & - & 5 & 2.81 & 5 & 2.34 \\
\hline 2000 & 1 & 2.78 & 5 & 2.81 & 6 & 2.80 \\
\hline 2001 & - & - & 5 & 2.81 & 5 & 2.34 \\
\hline 2002 & - & - & 6 & 3.37 & 6 & 2.80 \\
\hline 2003 & - & - & 3 & 1.69 & 3 & 1.40 \\
\hline 2004 & 1 & 2.78 & 4 & 2.25 & 5 & 2.34 \\
\hline 2007 & - & - & 6 & 3.37 & 6 & 2.80 \\
\hline 2008 & 2 & 5.56 & 5 & 2.81 & 7 & 3.27 \\
\hline 2009 & 1 & 2.78 & 9 & 5.06 & 10 & 4.67 \\
\hline 2010 & 3 & 8.33 & 11 & 6.18 & 14 & 6.54 \\
\hline 2011 & 1 & 2.78 & 4 & 2.25 & 5 & 2.34 \\
\hline 2012 & 2 & 5.56 & 9 & 5.06 & 11 & 5.14 \\
\hline 2013 & 2 & 5.56 & 4 & 2.25 & 6 & 2.80 \\
\hline 2014 & 1 & 2.78 & 3 & 1.69 & 4 & 1.87 \\
\hline 2015 & 2 & 5.56 & 3 & 1.69 & 5 & 2.34 \\
\hline 2016 & 1 & 2.78 & 9 & 5.06 & 10 & 4.67 \\
\hline 2017 & - & - & 8 & 4.49 & 8 & 3.74 \\
\hline 2018 & 2 & 5.56 & 4 & 2.25 & 6 & 2.80 \\
\hline Total & 36 & 100 & 178 & 100 & 214 & 100 \\
\hline
\end{tabular}

Table 8. Distribution of master's and doctorate theses written under the title of environmental problems by institutes.

\begin{tabular}{|c|c|c|c|c|}
\hline Institute & Doctorate & Master's & Total Frequency & Percentage $(\%)$ \\
\hline Institute of Marine Sciences and Management & 0 & 1 & 1 & 0.47 \\
\hline Institute of Education Sciences & 6 & 25 & 31 & 14.49 \\
\hline Graduate School of Natural and Applied Sciences & 6 & 38 & 44 & 20.56 \\
\hline The Graduate School of Engineering \& Sciences & 0 & 1 & 1 & 0.47 \\
\hline Middle East Technical University-Northern Cyprus Campus- Graduate School of Natural and Applied Sciences & 0 & 1 & 1 & 0.47 \\
\hline Institute of Middle East Studies & 0 & 1 & 1 & 0.47 \\
\hline Health Sciences Institute & 2 & 1 & 3 & 1.40 \\
\hline Social Sciences Institute & 22 & 110 & 132 & 61.67 \\
\hline Total & 36 & 178 & 214 & 100 \\
\hline
\end{tabular}

Theses written under the heading of environmental problems in Turkey does not have departments of $38.79 \%$ (Table 9), or could not be determined. The primary education department ranks first 
with $11.21 \%$ among those with a specific department. Public administration with $6.07 \%$, secondary school science and mathematics education with $4.21 \%$, and geography department with $3.74 \%$ are other departments in the top four.

Table 9. Distribution of master's and doctoral theses under title of environmental problems according to published department.

\begin{tabular}{|c|c|c|c|c|}
\hline Department & Doctorate & Master's & Total Frequency & Percentage (\%) \\
\hline Public Administration & 1 & 12 & 13 & 6.07 \\
\hline Environmental Engineering & - & 3 & 3 & 1.40 \\
\hline Geography & - & 8 & 8 & 3.74 \\
\hline Educational Sciences & 1 & 1 & 2 & 0.93 \\
\hline Social Sciences & 1 & - & 1 & 0.47 \\
\hline Biology Education & - & 1 & 1 & 0.47 \\
\hline Business Administration & - & 3 & 3 & 1.40 \\
\hline Farming Economy & 3 & 1 & 4 & 1.87 \\
\hline Social Environment Sciences & 3 & 4 & 7 & 3.27 \\
\hline Forest Engineering & 1 & - & 1 & 0.47 \\
\hline Landscape Architecture & - & 3 & 3 & 1.40 \\
\hline Economics & 2 & 5 & 7 & 3.27 \\
\hline Radio Television and Cinema & - & 1 & 1 & 0.47 \\
\hline Applied Sociology & - & 1 & 1 & 0.47 \\
\hline Finance & 2 & - & 2 & 0.93 \\
\hline Art History & - & 1 & 1 & 0.47 \\
\hline Home Economics and Nutrition Education & - & 2 & 2 & 0.93 \\
\hline Primary Education & 1 & 23 & 24 & 11.21 \\
\hline Marine Environment & - & 1 & 1 & 0.47 \\
\hline International Relations & 1 & 2 & 3 & 1.40 \\
\hline Field Crops & - & 1 & 1 & 0.47 \\
\hline Geological Engineering & - & 1 & 1 & 0.47 \\
\hline Environmental Sciences & - & 3 & 3 & 1.40 \\
\hline Sociology & - & 3 & 3 & 1.40 \\
\hline Labour Economics and Industrial Relations & - & 2 & 2 & 0.93 \\
\hline Secondary School Science and Mathematics Education & 2 & 7 & 9 & 4.21 \\
\hline Science Education & - & 2 & 2 & 0.93 \\
\hline Political Science and Public Administration & 1 & 2 & 3 & 1.40 \\
\hline Building Education & - & 1 & 1 & 0.47 \\
\hline Elementary Science Education & - & 1 & 1 & 0.47 \\
\hline Public Law & - & 1 & 1 & 0.47 \\
\hline Department of Social Sciences Education & - & 1 & 1 & 0.47 \\
\hline Chemical Science Education & - & 1 & 1 & 0.47 \\
\hline Middle East Geography & - & 1 & 1 & 0.47 \\
\hline Public Relations and Publicity & - & 1 & 1 & 0.47 \\
\hline Philosophy and Religious Sciences & 1 & - & 1 & 0.47 \\
\hline Fine Arts Education & 1 & - & 1 & 0.47 \\
\hline Philosophy & - & 2 & 2 & 0.93 \\
\hline Urban and Regional Planning & - & 1 & 1 & 0.47 \\
\hline English Language and Literature & 1 & - & 1 & 0.47 \\
\hline Sustainable Environment and Energy Systems & - & 1 & 1 & 0.47 \\
\hline Mathematics and Science Education & - & 3 & 3 & 1.40 \\
\hline Turkish and Social Sciences Education & - & 1 & 1 & 0.47 \\
\hline Public Health & 1 & - & 1 & 0.47 \\
\hline The Department does not exist or could not be determined & 13 & 70 & 83 & 38.79 \\
\hline Total & 36 & 178 & 214 & 100 \\
\hline
\end{tabular}

Gazi University, Istanbul University, Ankara University and Marmara University are universities that prepare the most doctorate and master's thesis under the title of environmental problems in Turkey (Table 10).

Under the title of environmental issues 8 doctorate theses and 26 master theses in Gazi University 34 theses in total have been prepared. Istanbul university is following this university with a total of 31 master and doctorate theses. On the other hand, a total of 26 theses at Ankara University and 11 theses at Maramara University have been prepared.

108 of the master's and doctoral theses (Table 11) on environmental problems determined in the National Thesis Center of the Council of Higher Education have been written at the Professor Doctor consultancy. In addition, 47 theses have been prepared at the Assoc.Dr. consultancy. Moreover 55 theses have been writen at the consultancy of Assist.Prof.Dr. While 1 thesis is being prepared at the consultancy of Dr. Lecturer, the title of the consultant of another master's thesis hasn't been determined.

66 of the 214 master and doctoral theses on environmental problems registered in the National Thesis Center of the Higher Education Council were written in Ankara. Regarding this title, 49 theses in Istanbul and 9 theses in Izmir have been written. (Table 12). Maximum doctoral theses were written in Ankara with 19 theses. Master's thesis at most were written in Ankara with 47 theses and in Istanbul with 41 theses. Moreover, thesis under the heading of environmental problems in 38 different cities in Turkey has prepared. 
Table 10. Distribution of master's and doctoral theses published under the title of environmental problems by universities.

\begin{tabular}{|c|c|c|c|c|}
\hline University & Doctorate & Master's & Total Frequency & Percentage (\%) \\
\hline Abant Izzet Baysal University & - & 1 & 1 & 0.47 \\
\hline Adnan Menderes University & - & 3 & 3 & 1.40 \\
\hline Afyon Kocatepe University & - & 3 & 3 & 1.40 \\
\hline Ahi Evran University & - & 2 & 2 & 0.93 \\
\hline Akdeniz University & - & 1 & 1 & 0.47 \\
\hline Anadolu University & 1 & 3 & 4 & 1.87 \\
\hline Ankara University & 9 & 17 & 26 & 12.19 \\
\hline Atatürk University & 1 & 2 & 3 & 1.40 \\
\hline Balıkesir University & - & 2 & 2 & 0.93 \\
\hline Celal Bayar University & - & 1 & 1 & 0.47 \\
\hline Cumhuriyet University & - & 4 & 4 & 1.87 \\
\hline Cağ University & - & 1 & 1 & 0.47 \\
\hline Canakkale Onsekiz Mart University & - & 1 & 1 & 0.47 \\
\hline Cukurova University & - & 3 & 3 & 1.40 \\
\hline Dokuz Eylül University & 2 & - & 2 & 0.93 \\
\hline Dumlupınar University & - & 3 & 3 & 1.40 \\
\hline Ege University & - & 7 & 7 & 3.27 \\
\hline Erciyes University & - & 2 & 2 & 0.93 \\
\hline Gazi University & 8 & 26 & 34 & 15.89 \\
\hline Gaziosmanpaşa University & - & 1 & 1 & 0.47 \\
\hline Gebze Institute of Technology & - & 1 & 1 & 0.47 \\
\hline Gümüşhane University & - & 1 & 1 & 0.47 \\
\hline Hacettepe University & 2 & 1 & 3 & 1.40 \\
\hline Inönü University & - & 6 & 6 & 2.80 \\
\hline Istanbul Teknik University & 2 & 3 & 5 & 2.34 \\
\hline Istanbul University & 3 & 28 & 31 & 14.49 \\
\hline Karadeniz Teknik University & - & 2 & 2 & 0.93 \\
\hline Kocaeli University & 2 & 3 & 5 & 2.34 \\
\hline Maltepe University & - & 1 & 1 & 0.47 \\
\hline Marmara University & 3 & 8 & 11 & 5.14 \\
\hline Mersin University & - & 1 & 1 & 0.47 \\
\hline Mimar Sinan Fine Arts University & - & 1 & 1 & 0.47 \\
\hline Muğla Sitk1 Koçman University & - & 1 & 1 & 0.47 \\
\hline Muğla University & - & 1 & 1 & 0.47 \\
\hline Mustafa Kemal University & - & 1 & 1 & 0.47 \\
\hline Namık Kemal University & 1 & 1 & 2 & 0.93 \\
\hline Necmettin Erbakan University & - & 3 & 3 & 1.40 \\
\hline Pamukkale University & - & 3 & 3 & 1.40 \\
\hline Sakarya University & - & 2 & 2 & 0.93 \\
\hline Selçuk University & 1 & 2 & 3 & 1.40 \\
\hline Süleyman Demirel University & - & 6 & 6 & 2.80 \\
\hline Trakya University & - & 2 & 2 & 0.93 \\
\hline Uludağ University & 1 & 4 & 5 & 2.34 \\
\hline Uşak University & - & 1 & 1 & 0.47 \\
\hline Yüzüncü Y1l University & - & 1 & 1 & 0.47 \\
\hline Total & 36 & 178 & 214 & 100 \\
\hline
\end{tabular}

Table 11. Distribution of master's and doctoral theses titled environmental problems according to advisor titles.

\begin{tabular}{lccc}
\hline Advisor & Doctorate & Master's & Total Frequency \\
\hline Prof.Dr. & 29 & 79 & 108 \\
Assoc.Prof.Dr. + Asst.Prof.Dr.(with two advisor) & - & 1 & 1 \\
Prof.Dr.+Dr. (with two advisor) & - & 1 & 1 \\
Assoc.Prof.Dr. & 5 & 42 & 47 \\
Asst.Prof.Dr. & 1 & 54 & 0.47 \\
Dr. Lecturer & 1 & - & 0.47 \\
Undetermined & - & 1 & 21.96 \\
Total & $\mathbf{3 6}$ & $\mathbf{1 7 8}$ & 1 \\
\end{tabular}

\section{DISCUSSION AND CONCLUSIONS}

It has been seen that in recent years studies prepared by bibliometric analyses have become very popular. It is easy to follow the development process of a science field thanks to the studies prepared by using bibliometry. In additation, it is also possible to plan for the future and to focus on problems if there are any (Altas \& Acar, 2018). In this context, master's and doctoral theses written under the title of environmental problems in Turkey have been discussed in detail in this part of the study.
Under the title of environmental problems in Turkey, 214 master's and doctoral theses written. 36 of these theses are doctoral theses and 178 are master theses. Doctoral theses constitute $16.82 \%$ of total theses, while master theses make up $83.18 \%$. Considering these rates, most of the theses made under the title of environmental problems are master's theses.

The fact that many of the master's students do not do doctorate is the biggest reason for the difference between master's and doctoral theses. Another reason for 
this situation is that the process of entering to the doctorate and getting education is more difficult compared to master's. In addition, the fact that some of the researchers turn to different fields is another factor that causes less doctorate theses to be written.

Table 12. Under the title of environmental problems distribution of master's and doctoral theses according to the provinces in which they were written.

\begin{tabular}{|c|c|c|c|c|}
\hline Province & Doctorate & Master's & Total Frequency & Percentage (\%) \\
\hline Ankara & 19 & 47 & 66 & 30.84 \\
\hline Istanbul & 8 & 41 & 49 & 22.90 \\
\hline Bolu & - & 1 & 1 & 0.47 \\
\hline Aydın & - & 3 & 3 & 1.40 \\
\hline Afyonkarahisar & - & 3 & 3 & 1.40 \\
\hline Kırşehir & - & 2 & 2 & 0.93 \\
\hline Antalya & - & 1 & 1 & 0.47 \\
\hline Eskişehir & 1 & 5 & 6 & 2.80 \\
\hline Erzurum & 1 & 2 & 3 & 1.40 \\
\hline Bilecik & - & 1 & 1 & 0.47 \\
\hline Manisa & - & 1 & 1 & 0.47 \\
\hline Sivas & - & 4 & 4 & 1.87 \\
\hline Mersin & - & 2 & 2 & 0.93 \\
\hline Canakkale & - & 1 & 1 & 0.47 \\
\hline Adana & - & 3 & 3 & 1.40 \\
\hline Kütahya & - & 3 & 3 & 1.40 \\
\hline Izmir & 2 & 7 & 9 & 4.21 \\
\hline Kayseri & - & 2 & 2 & 0.93 \\
\hline Kocaeli & 2 & 4 & 6 & 2.80 \\
\hline Gümüșhane & - & 1 & 1 & 0.47 \\
\hline Malatya & - & 6 & 6 & 2.80 \\
\hline Trabzon & - & 2 & 2 & 0.93 \\
\hline Muğla & - & 2 & 2 & 0.93 \\
\hline Hatay & - & 1 & 1 & 0.47 \\
\hline Tekirdağ & 1 & 1 & 2 & 0.93 \\
\hline Konya & 1 & 5 & 6 & 2.80 \\
\hline Niğgde & - & 2 & 2 & 0.93 \\
\hline Samsun & - & 1 & 1 & 0.47 \\
\hline Denizli & - & 3 & 3 & 1.47 \\
\hline Edirne & - & 2 & 2 & 0.93 \\
\hline Sakarya & - & 2 & 2 & 0.93 \\
\hline Bursa & 1 & 4 & 5 & 2.34 \\
\hline Uşak & - & 1 & 1 & 0.47 \\
\hline Isparta & - & 6 & 6 & 2.80 \\
\hline Van & - & 1 & 1 & 0.47 \\
\hline Total & 36 & 178 & 214 & 100 \\
\hline
\end{tabular}

Under the title of environmental problems in Turkey 96 graduate theses using qualitative research methods have been written. In addition 73 theses have been prepared using quantitative research methods. Using mixed research methods, 13 theses have been written and the research method of 32 theses has not been determined.

It has been observed that the researchers working under the title of environmental problems mostly adopt the qualitative research method in their master's and doctorate theses. As the reason for this; It is considered that numerical analysis of quantitative study data such as experiment, questionnaire, interview used in quantitative research methods is more difficult or these methods are not known to the researchers. It is considered that some researchers use mixed method to enrich their studies, if not high.

All 36 pieces of prepared doctoral thesis under the title of environmental problems in Turkey is written in Turkish. 174 of the 178 master's theses are written in Turkish and 4 in English. According to this data, only Turkish and English language was used master's and doctoral theses written under the title of environmental problems in Turkey.

The greatest factor in the use of the Turkish spelling language in such a high degree in master's and doctorate theses are the convenience of researching and writing in the native language. In addition, lack the desired level of foreign language teaching in Turkey and the difficulty of doing scientific studies in a foreign language, researchers are directed to write Turkish thesis.

$56.07 \%$ of the written theses under the title of environmental problems in Turkey is between 101 and 200 pages. The rate of thesis written under 100 pages in this title is $25.23 \%$. In addition, $15.42 \%$ of theses written in the same title are between 201 and 300 pages and $3.27 \%$ between 301 and 400 pages. There is not thesis written over 400 pages. More than half of the theses written under the title of environmental problems in Turkey, according to these data is between 101 and 200 pages. The majority of postgraduate theses with a page number of 201 and above are doctoral theses. The factor that causes this situation is 
that doctoral theses studies are more comprehensive than master's theses studies.

114 doctorate and master's theses which are written under the title of environmental problems in Turkey are accessible. But 100 theses are not accessible. Inaccessible thesis rate is $46.73 \%$. The total accessibility rate of theses is $53.27 \%$.

More than half of the theses written under the title of environmental problems in Turkey have been determined to be accessible. Especially, it was determined that doctorate and master's theses written up to the first half of the 1990s were registered in the Higher Education Council's Thesis Center by placing an access barrier by their authors. After 2000s, most of the theses written under the mentioned title are open to access. The fact that the theses are accessible will contribute to the development of the science field under this title in the coming period.

The majority of doctorate and master's theses are open to access on the internet as a result of the legal process in 2018 initiated by the initiative of the Council of Higher Education in Turkey. While the ratio of the number of accessible theses was $56.3 \%$ in 2017 , it increased to $98.7 \%$ in theses written in 2018. In 2017, 36610 theses were added to the system. And in the same year, 20617 theses were made accessible. In 2018, 41816 theses were added to the system. The number of theses open to access is 41314 in the same year. It is considered that $1.3 \%$ theses in 2018 to be inaccessible due to national security.

According to the ratio of all doctorate and master's theses open to accessibility (Table 13) announced by the Council of Higher Education in 2018, the accessibility rate of theses written until today under the title of environmental problems is low. Increasing the accessibility rate of the theses in this title will contribute to the scientists working in this science field in the future.

Table 13. Accessibility in recent years of master's and doctoral theses in Turkey (Education, 2019).

\begin{tabular}{cccc}
\hline Year & $\begin{array}{c}\text { Number of Theses } \\
\text { Added to the System }\end{array}$ & $\begin{array}{c}\text { Number of } \\
\text { Accessible Theses }\end{array}$ & $\begin{array}{c}\text { Percentage of } \\
\text { Accessible Theses }\end{array}$ \\
\hline 2017 & 36610 & 20617 & $\% 56.3$ \\
2018 & 41816 & 41314 & $\% 98.7$ \\
\hline
\end{tabular}

According to 2019 data, the number of users benefiting from the National Thesis Center has increased by $25 \%$ compared to the previous year and reached $5,036,614$ (Table 14). The number of people using the system was 4.019.895 in 2018. Consequently, it has observed that more than 1 million users used the system in a year (Council of Higher Education, 2020).

Between the years 1978-2006 under the heading of environmental problems in Turkey 124 theses were written. In addition between the years 2007 and 201890 theses were written under this title. Especially since 2006, the universities opened in Turkey's 81 provinces, a rapid increase in the number of theses work done under the title of environmental problems have generated.

132 of them in 214 theses written under the title of environmental problems in Turkey have prepared within the Graduate School of Social Sciences. 44 theses registered in Graduate School of Natural and Applied Sciences have been written. According to these data; The majority of the prepared doctoral and master's thesis in the title of environmental problems in Turkey has been in Graduate School of Social Sciences and Graduate School of Natural and Applied Sciences.

Table 14. Statistics of the Council of Higher Education Thesis Center (Council of Higher Education, 2020).

\begin{tabular}{lccc} 
Data Titles & $\begin{array}{c}\text { Year } \\
\mathbf{2 0 1 8}\end{array}$ & $\begin{array}{c}\text { Year } \\
\mathbf{2 0 1 9}\end{array}$ & $\begin{array}{c}\text { Increment } \\
(\mathbf{\%})\end{array}$ \\
\hline $\begin{array}{l}\text { Number of Users } \\
\begin{array}{l}\text { Number of Theses Registered to } \\
\text { the Database }\end{array}\end{array}$ & 4.019 .895 & 5.036 .614 & 25 \\
$\begin{array}{l}\text { Number of New Theses Added to } \\
\text { the System }\end{array}$ & 520.456 & 594.578 & 14 \\
Number of Theses Download & 41816 & 74.122 & 77 \\
Number of Page views & 14.640 .189 & 16.364 .817 & 12 \\
\hline
\end{tabular}

Doctorate and master's theses in 44 different departments under the title of environmental problems in Turkey has been prepared. Analyzing of the title of environmental problems by many departments will contribute to addressing the issue from different perspectives and to bring many scientific works into the literature. Under this title, the deparments of 83 theses is not specified in the National Thesis Center of the Higher Education Council. However, all theses written after 2006 have been written within the department. The reason for this situation is that the entrance of the department is obligatory during data upload to the system depending on the development of the technology.

Gazi University, Istanbul University, Istanbul Technical University, Ankara University, Mimar Sinan Güzel Sanatlar University and Marmara University which are universities with the most theses written under the title of environmental problems in Turkey. The reason for this situation is the high number of opportunities that these universities in the metropolitan cities offer to researchers. In addition, the locations of these universities are cities where environmental problems are intensely experienced.

108 of the doctoral and master's theses written under the title of Environmental Problems was written with the advisor holding the title of Professor Doctor. 47 theses under the advisor of Associate Professor Doctor and 55 theses under the advisor of Assistant Professor Doctor were written. In this context, there is no hierarchy between title and thesis advisory. In addition, one thesis was prepared under the advisor of Doctor Lecturer. The reason is that, this title began to be used in 2018 . 
The highest number of master's and doctoral theses under the title of environmental problems in Turkey have been written Ankara, Istanbul and Izmir provinces. The redundancy of population and university in these cities can be considered as the reason for this situation. It is a positive situation that a large number of thesis studies are carried out in universities in these provinces where environmental problems are intense.

In this study, while seeking theses in the National Thesis Center of the Higher Education Council, environmental problems title was written in the field of scanning. In the future, new studies can be done by searching the words of environment, environmental policy and environmental law.

Before the theses are submitted, books, articles and theses related to bibliometric studies in the world and Turkey must be investigated with detailed. Thus, some errors encountered in the studies to be carried out within the subject will be reduced. In addition, it is thought that repeating the studies conducted in this field at certain intervals will contribute to the updating and enrichment of the literature. In the future, country, science, and public and private sector comparisons producing publications will also contribute to the literature.

\section{REFERENCES}

Akkocaoglu, S. (2019). A comprehensive bibliometric analysis of documents of organization theories on social entrepreneurship. Master's Thesis, At1lim University Social Sciences Institute. Ankara, Turkey, 145p.

Aksaray, O. (2019). Bibliometric analysis of theses in music abstract. Kurıkkale University Social Sciences Institute. Kırıkkale, Turkey, 63p.

Al, U. (2008). Scientific publication policy of Turkey: A bibliometric approach based on citation indexes. Master's Thesis, Hacettepe Üniversity Social Sciences Institute. Ankara, Turkey, 230p.

Altas, A. \& Acar, Y. (2018). Bibliometric profile of the postgraduate dissertations written in the field of gastronomy. Journal of Aksaray University Faculty of Economics and Administrative Sciences. 10(3), 110.

Altıntop, V. (2019). Bibliometric analysis of cultural tourism studies. Doctorate Thesis, Gazi University Social Sciences Institute. Ankara, Turkey, 160p.

Baykal, H. \& Baykal, T. (2008). Environmental problems in a globalized world. Mustafa Kemal University Journal of Social Sciences Institute, 5(9), 1-17.

Cinar, B. (2019). Evaluation of scientific publications in international trade with social network analysis: A bibliometric study. Master's Thesis, Alanya Alaaddin Keykubat University Social Sciences Institute. Alanya-Antalya, Turkey, 95p.
Coskun, S.K. (2020). Tourism and Islamophobia in the field of bibliometric analysis. Master's Thesis, Selçuk University Social Sciences Institute. Konya, Turkey, $145 \mathrm{p}$.

Council of Higher Education. (2019). Thesis center. Date of access: 13.05.2019, https://tez.yok.gov.tr/ UlusalTezMerkezi/tezSorguSonucYeni.jsp.

Council of Higher Education. (2020). Statistics of National Thesis Center. Date of access:18.03.2020, https://www.yok.gov.tr/

Sayfalar/Haberler/2020/yok-ulusal-tez-merkeziistatistikleri.aspx.

Deniz, B.D. (2019). A bibliometric analysis of critical construction management studies. Master's Thesis, Izmir Institute of Technology The Graduate School of Engineering \& Sciences. Izmir, Turkey, 155p.

Emre, Y. (2019). The early stages of organization and management studies in North America and Europe: A bibliometric analysis. Master's Thesis, Muğla Sitk1 Koçman University Social Sciences Institute. Muğla, Turkey, 107p.

Hurriyet. (2019). Education. Date of access: 17.02.2020, https://www.hurriyet.com.tr/egitim/erisime-aciktez-sayilarinin-orani-yuzde-99a-cikti-41079989.

Karaboga, H.A. (2019). Bibliometric analysis of organizational behavior research. Master's Thesis, Yıldız Teknik University Social Sciences Institute. Istanbul, Turkey, 132p.

Kaypak, Ş. (2013). The global environmental politics for the solution of environmental problems. Muğla University Journal of Social Sciences Institute, 31, 17-34.

Kefkir, T.A. (2019). Bibliometric analysis of management information systems discipline. Master's Thesis, Başkent University Social Sciences Institute. Ankara, Turkey, 91p.

Koehler, W. (2001). Information science as "Little Science": The implications of a bibliometric analysis of the Journal of the American Society for Information Science. Scientometrics, 51(1), 117132.

Oguz, M.C. (2019). Ethics in STS: A bibliometric exploratory study. Master's Thesis, Ozyeğin University Social Sciences Institute. Cekmeköy-Istanbul, Turkey, $118 \mathrm{p}$.

Percin, H. (2019). Examination of concept of open innovation in the World and Turkey with bibliometric, content and document analysis. Master's Thesis, Izmir Katip Çelebi University Social Sciences Institute. Izmir, Turkey, 222p.

Satır, A. (1998). Bibliometric analyses. Master's Thesis, Hacettepe University Graduate School of Natural and Applied Sciences. Ankara, Turkey, 58p.

Subramanyam, K. (1983). Bibliometric studies of research collaboration: A review. Journal of information Science, 6(1), 33-38.

Taskın, Z. \& Çakmak, T. (2010). Bibliometric profile of information world since the beginning. Information World, 11(2), 332-348.

Tubitak Ulakbim Cahit Arf Information Center. (2020). Bibliometric analysis. Date of access: 18.02.2020, https://cabim.ulakbim.gov.tr/bibliyometrik-analiz. 